NBER WORKING PAPER SERIES

\title{
ENDOGENOUS FINANCIAL OPENNESS: EFFICIENCY AND POLITICAL ECONOMY CONSIDERATIONS
}

\author{
Joshua Aizenman \\ Ilan Noy \\ Working Paper 10144 \\ http://www.nber.org/papers/w10144
}

\author{
NATIONAL BUREAU OF ECONOMIC RESEARCH \\ 1050 Massachusetts Avenue \\ Cambridge, MA 02138
}

December 2003

We would like to thank Shang-Jin Wei for sharing the data on financial openness. We would also like to thank for useful comments we received from Carl Bonham, Mike Dooley, Doireann Fitzgerald, Byron Gangnes, Ken Kletzer, Xenia Matschke, Donald Wittman, Ari van Asche and the seminar participants at UCSC, University of Hawaii and University of Washington. Any errors are ours. The views expressed herein are those of the authors and not necessarily those of the National Bureau of Economic Research.

(C)2003 by Joshua Aizenman and Ilan Noy. All rights reserved. Short sections of text, not to exceed two paragraphs, may be quoted without explicit permission provided that full credit, including $(\mathrm{C}$ notice, is given to the source. 
Enogenous Financial Openness: Efficiency and Political Economy Considerations

Joshua Aizenamn and Ilan Noy

NBER Working Paper No. 10144

December 2003

JEL No. F15, F21, F36, H21

\section{ABSTRACT}

This paper studies the endogenous determination of financial openness. We outline a framework where financial openness is endogenously determined by the authority's choice of financial repression as a taxation device, and where the private sector determines endogenously the magnitude of capital flight. The optimal financial repression is shown to depend on the openness of the economy to international trade, the efficiency of the tax system (which in turn may be affected by political economy considerations), and on political polarization and the degree of opportunism. Similar predictions are obtained in a model where authorities pursue an opportunistic policy representing the interest of a narrow pressure group that engages in capital flight due to political uncertainty. We confirm the predictions of the models, showing that de-facto financial openness [measured by (gross private capital inflows + outflows)/GDP] depends positively on lagged trade openness, and GDP/Capita. For developing countries, we find that a one standard deviation increase in commercial openness is associated with a 9.5 percent increase in de-facto financial openness $(\%$ of GDP), a one standard deviation increase in the democratization index reduces financial openness by $3.5 \%$, and a one standard deviation increase in corruption is associated with a $3 \%$ reduction of financial openness. Similar negative dependence applies for measures of political competition. The impact of a budget surplus on financial openness is negative for developing countries, but positive for the OECD. The theoretical and empirical analysis leads us to conclude that a more openly competitive, free and inclusive political system will lead to lower levels of de-facto financial openness after controlling for incomes, macroeconomic policy (inflation and budget surpluses), interest rates and commercial openness.

Joshua Aizenman

Department of Economics

317 Social Science 1

UC Santa Cruz

1156 High Street

Santa Cruz, CA 95064

and NBER

jaizen@ucsc.edu
Ilan Noy

Department of Economics

Suanders Hall 542

University of Hawaii, Manoa

2424 Maile Way

Honolulu, HI 96822

noy@hawaii.edu 


\section{Introduction and overview}

Salient features of the last twenty years have been the growing financial integration of developing countries, and recurring financial crises. These developments have led to contentious debate regarding the desirability of financial openness. Prominent economists have concluded that the gains from financial integration are illusive, cautioning developing countries not to rush towards financial openness [see Rodrik (1999) and Stiglitz (2002)]. Yet, other studies have provided tentative support for the presence of significant gains from financial openness [see Bekaert et. al. (2002) and Henry (2003)]. These studies frequently focus on the formal acts associated with de-jure financial opening, such as changing regulations and the attitude of the central bank and the treasury to financial flows. Yet, as has been noted by Prasad, Rogoff, Wei and Kose (2003), de-facto financial integration by itself, is of considerable interest. Indeed, the actual level of financial openness [measured by (gross private capital inflows + gross private outflows)/GDP] is the outcome of the interaction between market forces and enforcement of existing regulations. The purpose of our paper is to focus on these links. In particular, we highlight the endogenous determination of financial integration, showing that de-facto financial openness is the outcome of macro-economic, public finance and political economy considerations. As we argue in the concluding remarks, understanding the links between the economic/political economy structure and de-facto financial integration is a pre-condition for evaluating the challenges, risks and benefits associated with de-jure financial integration.

In Section 2 we outline two polar models where financial openness is determined endogenously. The first case describes a representative agent, public finance model of a developing country where the benevolent authorities finance a given fiscal outlay by means of distortionary taxes. The second case models a scenario where authorities pursue an opportunistic policy representing the interest of a narrow pressure group that engages in capital flight due to political uncertainty. Interestingly, the two models provide similar predictions about the links between commercial openness, political economy factors and de-facto financial openness. 
In the public finance model, financial openness is endogenously determined by the authority's choice of financial repression, and the private sector determines endogenously the magnitude of capital flight. Capital flight is intermediated via trade mis-invoicing, and exposes agents to the risk of interception and ultimately, confiscation of funds. ${ }^{1}$ Agents view this risk as exogenous, and determine their optimal portfolio by weighing the gain from the higher interest rate on offshore deposits against the risk of confiscation. We characterize the optimal portfolio as a function of the attitude towards risk, the probability of capital flight interception, and the relevant interest rates. While the probability of intercepting capital flight is exogenous for the atomistic agent, it is endogenously determined by policies and the economic structure. Specifically, greater trade openness would make it easier to intermediate a given volume of capital flight. Hence, the probability of intercepting capital flight of a representative agent increases with the resources spent on enforcement relative to the trade openness, and declines with the magnitude of the aggregate capital flight.

The problem facing the fiscal authorities is to fund given fiscal outlays on public goods relaying on two types of taxes: income tax, and financial repression. Both taxes are costly: income tax is associated with collection costs, and enforcing financial repression requires direct expenditure on monitoring and policing trade invoices, etc. We show that financial repression characterizes countries that are below a certain threshold of fiscal efficiency - high enough cost of tax collection would induce the implementation of financial repression as a means of taxation. In these circumstances, higher tax collection costs, higher fiscal expenditure and lower commercial openness would increase the “optimal” financial repression.

Applying the insight of Cukierman, et al. (1992), we expect that the cost of tax collection itself is endogenously determined. Functioning democracies will tend to have more efficient tax collection systems, and thus tend to be associated with lower capital flight. Similarly, we expect less polarized societies and those in which conflicts are

\footnotetext{
${ }^{1}$ See Giovannini and de Melo (1993) for documenting and measuring financial repression as an implicit tax on savings, and Kletzer and Kohli (2003) for analysis of the fiscal implications of financial repression in India. See Dooley (1988), Tornell and Velasco, (1992), and Dooley and Kletzer (1994) on capital flight as a mean of political economy risk diversification. See Dooley (1996) for an overview of financial controls; and Claessens and Naudé (1993) and Boyce and Ndikumana (2001) for discussions on trade mis-invoicing and capital flight.
} 
solved peacefully within the political system to have more efficient tax collection mechanisms in place, reducing capital flight motivated by tax evasion and/or opportunistic behavior, looting, etc.

We close Section 2 with the polar case, corresponding to high degrees of opportunism and political uncertainty. Here, first period policies are determined by a policy maker representing a narrow interest group facing political uncertainty. Specifically, we consider the case where the policy maker controls foreign exchange income from exporting a natural resource in the first period, and faces an uncertain future horizon. In these circumstances, his second period consumption would be partly determined by the income from first period savings, conveniently put offshore, beyond the control of the future regime. Second period output of the natural resource is impacted by the tangible investment in the extraction of the resource. Such an investment can be financed by the income controlled by the present policy maker. Alternatively, outsiders, willing to bet that there is a positive chance that they will gain control of the surplus in the second period, can finance the investment. We illustrate that with opportunistic behavior, the combination of policy uncertainty and polarization would lead to greater de-facto financial openness.

In section 3 we examine empirically some of the hypotheses suggested by our models. We estimate the level of de facto financial openness as a function of lagged trade openness, several macroeconomic control variables, and a vector of politicalinstitutional variables. We apply a two-step FGLS procedure for a panel of developing and OECD countries for the years 1982-1998 using annual observations [the sample size was determined by the availability of data and by excluding small-island economies]. We find that de-facto financial openness depends positively on lagged trade openness, and the GDP/Capita. The budget surplus to GDP ratio is occasionally significant and always negative for developing countries, but positive and significant for the OECD countries. Including the corruption variable in our regressions also yields negative and significant coefficients in almost all the iterations of the model we examined, confirming Wei's (2000) insight. For the full sample (developing and the OECD) and the developing countries sub-samples, the effect of greater democratization is negative, significant and apparently large. Any one-point increase in this index (out of the 20 points difference 
between full autocracy and democracy) reduces financial openness (international financial flows) by almost a one-half percentage point of GDP. The effect is about half as large when we do not control for the level of corruption.

We further investigate the political-economy nature of financial openness by replacing the democracy/autocracy (regime) variable with two others: a measure of political competition and an index of government fractionalization. For the political competition variable, we find that increased institutionalized competition within the polity decreases financial openness. As we observed before, this effect is more perceptible and significant once corruption is controlled for as well. We also find that the more a government is fractionalized (the ruling coalition includes more political parties), the higher is financial openness. Section 4 concludes the paper with interpretive remarks.

\section{The model}

We consider two polar versions of models where financial openness is determined endogenously. The first is a representative agent model, of a developing country where the benevolent authorities finance a given fiscal outlay by means of distortionary taxes. The second is the case where authorities pursue an opportunistic policy representing the interest of a narrow pressure group that engages in capital flight due to political uncertainty.

\subsection{The public finance model}

The utility of the representative consumer, $i$, is given $b^{2}$

$$
V_{i}=u\left(C_{1, i}\right)+\frac{u\left(C_{2, i}\right)}{1+\rho},
$$

where $C$ is the consumption of the domestic good. The production of the home good uses domestic and foreign traded inputs:

$$
k X^{\alpha} Y^{\beta} \quad ; \quad 0<\alpha, \beta, \quad \alpha+\beta=1,
$$

\footnotetext{
${ }^{2}$ The present model extends Aizenman and Guidotti (1994) and Aizenman (2003), by allowing the endogenous linkage between commercial and financial openness, in circumstances where capital flight is subject to stochastic confiscation.
} 
and $k$ is a normalization factor, $k=\frac{1}{\alpha^{1-\alpha} \beta^{\beta}}$. To simplify, we normalize the prices of both the domestic and the foreign inputs to one. The representative consumer starts period 1 with past savings of $\bar{S}_{i,-1}\left(1+r_{-1}\right)$. At the beginning of each period, the representative consumer is endowed with $\bar{X}_{i}$ units of the domestic input. The aggregate endowment is denoted by $\bar{X}$,

(3) $\bar{X}=\sum_{i} \bar{X}_{i}$.

The Cobb-Douglas production (2) implies that aggregate imports are

(4) $\beta C$

The fiscal authorities tax the endowment $\bar{X}$ and the interest rate income a rate $t$. The consumer allocates savings between domestic and foreign bonds, $S$ and $F$, respectively, such that

(5) $\quad C_{1, i}=\bar{X}_{i}(1-t)+S_{0, i}\left[1+(1-t) r_{0}\right]-S_{i}-F_{i}$,

where $S_{0, i}$ is savings in period zero, yielding interest rate $r_{0}$. The fiscal authorities impose capital control, leading to random interception of illicit capital flight. Let $\phi$ denote the probability of intercepting agent $i$ 's illicit capital flight, leading to confiscation. Hence, the second period consumption is contingent on the success $(s)$ or failure $(f)$ of capital flight:

(6) $C_{2, i}=\left\{\begin{array}{lr}C_{2, i}^{s}=(1-t) \bar{X}_{i}+S_{i}(1+r(1-t))+F_{i}\left(1+r^{*}\right) & \text { with probability } 1-\phi \\ C_{2, i}^{f}=(1-t) \bar{X}_{i}+S_{i}(1+r(1-t)) & \text { with probability } \phi\end{array}\right.$.

\subsection{Consumer's optimization}

The allocation problem of the representative consumer is summarized by

$$
\begin{aligned}
& M A X E\left[u\left(C_{1, i}\right)+\frac{(1-\phi) u\left(C_{2, i}^{s}\right)+\phi u\left(C_{2, i}^{f}\right)}{1+\rho}\right], \\
& S, F
\end{aligned}
$$


Each consumer is small, thereby treating as exogenous the probability of capital flight interception. The first order conditions associated with optimal domestic and foreign savings are

$$
\begin{aligned}
& u^{\prime}\left(C_{1}\right)=\frac{(1-\phi)\left(1+r^{*}\right)}{1+\rho} u^{\prime}\left(C_{2, s}\right) ; \\
& u^{\prime}\left(C_{1}\right)=\frac{1+r(1-t)}{1+\rho}\left[(1-\phi) u^{\prime}\left(C_{2, s}\right)+\phi u^{\prime}\left(C_{2, f}\right)\right]
\end{aligned}
$$

Applying (8) and (9), the equilibrium spread between the foreign and the domestic interest rates facing the consumer is:

$$
\frac{r^{*}-r(1-t)}{1+r^{*}}=\phi \frac{\Omega}{1-\phi+\phi \Omega} \quad \text { where } \Omega=\frac{u^{\prime}\left(C_{2, i}^{f}\right)}{u^{\prime}\left(C_{2, i}^{s}\right)}
$$

The premium between the foreign and the domestic after-tax real interest rates compensates for the probability of intercepting the illicit capital flight, $\phi$, at a rate reflecting the consumer's attitude towards risk. ${ }^{3}$ Henceforth we use $\phi$ as a measure of the de-facto financial repression. Applying the first order conditions (8) and (9), it can be verified that $\frac{d F_{i}}{d \phi}<0$ and $\frac{d F_{i}}{d t}>0$-- higher financial repression $\phi$ and lower tax rate $t$ reduce the expected yield on offshore saving, reducing capital flight.

\subsection{Endogenous enforcement}

While the private agent views the probability of intercepting capital flight as given, the actual value is determined by the fiscal resources spent on enforcing capital controls, and by other macro variables impacting the efficacy of these controlṣ. We assume $\phi$ to depend positively on the ratio of resources spent on enforcement relative to the capacity to engage in illicit capital flows. Specifically, we denote by $\tau$ the fraction of endowment spent by the fiscal authorities enforcing capital controls. The experience of developing countries has illustrated that exports under-invoicing and imports overinvoicing have been important channels facilitating capital flight. In these circumstances,

\footnotetext{
${ }^{3}$ The term $\Omega$ is the ratio of the marginal utility of consumption in the case when the illicit capital is intercepted, relative to the case when the authorities fail to intercept. The premium increases with the probability of interception, and with the degree of risk aversion.
} 
intermediating a given volume of capital flight would be easier in countries that are more open to international trade. Recalling that imports are proportional to $\beta$, we assume $\phi$ to depend positively on the enforcement/import rate, $\tau / \beta$. We summarize the assumptions in a reduced form

$$
\phi=\phi\left[\frac{\tau}{\beta}, F\right] ; \quad \phi_{1}^{\prime}>0 ; \quad \phi_{2}^{\prime}<0 ; \phi_{1,1}^{\prime \prime}<0 ; \phi_{1,2}^{\prime \prime}<0 \quad ; \text { where } F \text { is the }
$$

aggregate capital flight [i.e., $F=\sum_{i} F_{i}$ ]. Higher capital flight implies fewer resources devoted to supervision per unit of capital flight, reducing the probability of intercepting a dollar of capital flight [though the total confiscation $F \phi$ would increase].

The enforcement of income and interest rate taxes is associated with collection cost $\lambda$ per one dollar of gross taxes, implying that the net tax collected by a tax $t$ is $(1-\lambda) t$. The fiscal budget constraint in period one is:

$$
t(1-\lambda)\left[\bar{X}+S_{-1} r_{-1}\right]+S=G+\tau \bar{X}+\bar{S}_{-1}\left(1+r_{-1}\right) .
$$

The net revenue from the income tax, plus the revenue from the domestic bond sold in period one finances the fiscal expenditure on public good $(G)$, plus the cost of enforcing capital controls, plus the repayment of old debt. Similarly, the second period fiscal budget constraint is

$$
t(1-\lambda)[\bar{X}+S r]+\phi F\left(1+r^{*}\right)=G+S(1+r) .
$$

Applying (10), (12) and (13) we consolidate the two budget constraints into the intertemporal one:

$$
\begin{aligned}
& t\left\{\bar{X}\left[1+\frac{1}{1+r^{*}}\right]+S_{0} r_{0}\right\}+\phi F+S[\phi+\phi(1-\phi) \Gamma]= \\
& G\left[1+\frac{1}{1+r^{*}}\right]+S_{0}\left(1+r_{0}\right)+\tau \bar{X}+\lambda t\left\{\bar{X}\left[1+\frac{1}{1+r^{*}}\right]+S_{0} r_{0}+\frac{S r}{1+r^{*}}\right\}
\end{aligned}
$$

where $\Gamma=\frac{\Omega-1}{1-\phi+\phi \Omega}$.

The left hand side of (14) is the gross tax revenue. It is the sum of the net present value of the endowment tax and the tax on interest paid on the initial public debt (the first term), plus the "confiscation tax" on foreign bonds, $F$, at the rate $\phi$ (which equals the probability of intercepting capital flight), plus the implicit tax on domestic bonds, at a 
rate $\phi+\phi(1-\phi) \Gamma$. For a risk neutral consumer, expected yields on the domestic bond should match the expected yield on the foreign bond, $\left(1+r^{*}\right)(1-\phi)$. This is equivalent to imposing an implicit tax on first period savings at the rate $\phi$ (which equals the probability of intercepting capital flight). ${ }^{4}$ Risk aversion magnifies the implicit tax induced by financial repression -- it further reduces the equilibrium cost of the public debt, by $\phi(1-\phi) \Gamma$. This term is the risk premium demanded by the holders of foreign bonds, needed to compensate for the confiscation risk. Unlike the private sector, the effective real interest rate facing the fiscal authorities equals the foreign interest rate. The RHS of (14) is the net present value of government outlays, which equals the net present value of the public good [the first term], plus financing the repayment of the outstanding initial pubic debt, plus financing the enforcement of capital controls and the cost of collecting taxes.

Equation (14) is the fundamental budget constraint facing the government. It defines implicitly a trade off between financial repression (as determined by the resources spent on enforcement) and the endowment tax: $t=t(\tau)$. The policy maker chooses the tax rates $\tau$ and the corresponding $t$ determined by (14) that would maximize the utility of the representative agent.

It is convenient to normalize the endowment, and henceforth we assume that $\bar{X}=1$. In the appendix we show that, for small changes,

$$
\begin{aligned}
& \frac{d V}{d \tau} \frac{1}{u^{\prime}\left(C_{1}\right)}= \\
& -\left\{\left[1+\frac{1}{1+r(1-t)}\right]+S_{0} r_{0}\right\} \frac{d t}{d \tau}-\frac{1+r^{*}-[1+r(1-t)](\Omega-1)}{\left(1+r^{*}\right)(1-\phi)} S \phi_{\tau}^{\prime}+\frac{u\left(C_{2, f}\right)-u\left(C_{2, f}\right)}{1+\rho} \phi_{\tau}^{\prime}
\end{aligned}
$$

A useful benchmark is full financial integration, i.e. $\tau=0$, where $\phi=0, r(1-t)=r^{*}, \Omega=1$. The welfare effect of imposing marginal financial repression is

$$
\left.\frac{d V}{d \tau} \frac{1}{u^{\prime}\left(C_{1}\right)}\right|_{\tau=0}=\left(-\left.\frac{d t}{d \tau}\right|_{\tau=0}\right)\left[1+\frac{1}{1+r^{*}}+S_{0} r_{0}\right]-S \phi_{\tau}^{\prime}
$$

\footnotetext{
${ }^{4}$ In terms of (14), risk neutrality implies $\Gamma=0$, reducing the yield on domestic bonds to $[\phi+\phi(1-\phi) \Gamma]_{\mid \Gamma=0}=\phi$. Note that our analysis understates the revenue from financial repression part of it comes from taxing domestic financial intermediation. Adding the domestic banking system would not affect the paper's main results.
} 
Imposing financial repression would allow reducing the tax rate $\mathrm{t}$ by $-\frac{d t}{d \tau}$, inducing a welfare gain equal to the drop in the tax rate times the relevant tax base. This welfare gain is offset by the adverse welfare effect associated with shifting the tax burden from an endowment tax to taxing savings, measured by the last term on the RHS of (16). Applying (12) and (14) we infer that, in the vicinity of full financial integration, government's intertemporal budget constraint induces the following trade off:

$$
\left.\frac{d t}{d \tau}\right|_{\tau=0}=-\frac{S\left[1+\lambda \frac{t}{1-t}\right] \phi_{\tau}^{\prime}-1+\lambda \frac{t r^{*}}{1+r^{*}}}{\left\{1+\frac{1}{1+r^{*}}+S_{0} r_{0}\right\}(1-\lambda)+\lambda \frac{r^{*}}{1+r^{*}}\left[(1-\lambda) t\left\{1+S_{0}\left(1+r_{0}\right)\right\}-\frac{S}{1-t}\right]}
$$

In the presence of lump sum income (i.e., $\lambda=0$ ), equation (17) reduces to

$$
\left.\frac{d t}{d \tau}\right|_{\tau=0, \lambda=0}=-\frac{S \phi_{\tau}^{\prime}-1}{1+\frac{1}{1+r^{*}}+S_{0} r_{0}} .
$$

As long as $S \phi_{\tau}^{\prime}-1>0$, spending on enforcing capital controls increases net revenue, allowing cutting the income tax rate, t. Hence, $\left.S \phi_{\tau}^{\prime}\right|_{\tau=0}>1$ is a necessary condition for financial repression to be considered as a viable policy option. ${ }^{5}$ Henceforth we will assume it to hold. Applying (17) to (15) we infer that

$$
\left.\frac{d V}{d \tau} \frac{1}{u^{\prime}\left(C_{1}\right)}\right|_{\tau=0, \lambda=0}=-1 \text {. }
$$

With a lump sum endowment tax, there are no benefits associated with financial repression, and the welfare effect of a dollar spent on enforcing marginal capital controls reduces welfare by exactly one dollar. However, high enough collection costs would imply that financial repression leads to a large drop in the cost of collecting conventional taxes, inducing the tax authorities to add financial repression to the menu of taxes. ${ }^{6}$ In these circumstances, the optimal depth of capital control is characterized by (15).

\footnotetext{
${ }^{5}$ The condition $S \phi_{\tau}^{\prime}>1$ indicates that the economy operates on the left side of the Laffer curve associated with financial repression.

${ }^{6}$ Note that the numerator of (17) increases with the cost of tax collection, $\lambda$, whereas the denominator is positive for low $\lambda$, approaching zero for a large enough tax collection cost, implying that (17) approaches infinity for high enough $\lambda$.
} 
Assuming that the cost of tax collection is high enough to induce positive but low financial repression, we can apply (15) and (17) to infer

\section{Claim 1:}

High enough tax collection costs would induce the implementation of financial repression. Under these circumstances, higher tax collection costs, $\lambda$, higher fiscal expenditure $\mathrm{G}$ and lower commercial openness would lead to increased "optimal" financial repression -- $\frac{d \phi}{d \lambda}>0 ; \frac{d \phi}{d G}>0 ; \frac{d \phi}{d \beta}<0 \quad$ [see the Appendix for derivation].

Following the approach of Cukierman, Edwards and Tabellini (1992), one expects less polarized societies and better functioning democracies to be characterized by more efficient tax collection systems [hence by lower $\lambda$ ]. Applying this conjecture, a more efficient tax system would be associated also with a lower tax rate, $t$, thereby reducing the attractiveness of capital flight. It can be verified that with low enough financial repression, the net effect of improving the tax system is to lower the incidence of capital flight, thereby reducing de-facto financial integration.

Of course, de-facto financial openness is impacted by other considerations not addressed by the public finance model described above, such as differentials in discount rates and investment opportunities across countries, etc. One should view the above model as suggestive of possible links between macro and political economy factors and de-facto openness, motivating the empirical research. Yet, we do not claim that our empirical work summarized in the next section is a test of this model. In fact, we argue that the links we identify may be attributed to other economic forces, explained by alternative models. To illustrate this point, we close this section by contrasting our public-finance model with (arguably) the opposite case, where financial openness is determined by pure opportunism associated with looting. ${ }^{7}$

\footnotetext{
${ }^{7}$ Russia in the early nineties may provide a good case study. See Akerlof and Romer (1993). See also Alesina and Tabellini (1989) for a model where political instability and the polarization between labor and capital determines the incidence of capital flight and financial openness.
} 


\section{$2.4 \quad$ Political uncertainty, opportunistic model}

A fair criticism of the public finance approach described above is that it more accurately describes homogenous countries, where the policy maker is guided by the interests of the median voter, and there is little political uncertainty pertaining to competing parties and competing interest groups. Hence, it is useful to consider the polar case, corresponding to high degrees of opportunism and political uncertainty. One expects that most countries are characterized by regimes on a continuum between these two polar cases. Interestingly, we will illustrate that both approaches may lead to similar links between macroeconomic and political economy variables and de-facto financial openness. We describe now a simple model summarizing de facto financial openness under circumstances where policies in the first period are determined by a policy marker representing a narrow interest group facing political uncertainty. Specifically, suppose that the policy maker controls foreign exchange income from exporting a natural resource in the first period, and faces an uncertain future horizon. With probability $q$, a new government will take over in period 2, ousting the first period policy maker. In these circumstances, his second period consumption would be determined by the income from the first period savings, conveniently put offshore, beyond the control of the future regime. The second period output of the natural resource is impacted by the tangible investment in the extraction of the resource. Such an investment can be financed by the income controlled by the present policy maker. Alternatively, it can be financed by outsiders who are willing to bet that, with probability $1-\mathrm{q}$, they will gain control of the surplus in the second period. For concreteness, suppose that the situation is summarized by the following equations:

$$
\begin{aligned}
& \text { (20) } M_{1}=M\left(K_{1}\right) ; M_{2}=M\left(K_{1}+I+I^{*}\right), \quad M^{\prime}>0 ; M^{\prime \prime}<0 \\
& \text { (21) } u\left(C_{1}\right)+\frac{u\left(C_{2}\right)}{1+\rho}
\end{aligned}
$$

where $M_{t}$ in (20) is the surplus generated by the natural resource at time $\mathrm{t}(\mathrm{t}=1,2)$. The second period surplus depends positively on first period investments, $I$ and $I^{*}$, corresponding to the investment financed by the first period policy maker and the outsider party, respectively. $K_{1}$ is the initial stock of capital. 
Equation (21) represents the utility of the policy maker. To simplify, we assume that the outside party is risk neutral. The policy maker determines the first period investment and saving by solving

$$
\underset{S, I}{M A X}\left[u\left(M_{1}-S-I\right)+\frac{q u\left(S\left[1+r^{*}\right]\right)+(1-q) u\left(S\left[1+r^{*}\right]+M_{2}\right)}{1+\rho}\right]
$$

The problem facing the outside party is

$$
M A X\left[-I^{*}+\frac{q M_{2}}{1+\rho}\right] \text {. }
$$

$$
I^{*}
$$

The first order conditions are

$$
\begin{aligned}
& -u_{1}^{\prime}+\frac{1+r^{*}}{1+\rho}\left[q u_{2, l}^{\prime}+(1-q) u_{2, h}^{\prime}\right]=0 ; \\
& -u_{1}^{\prime}+\frac{1}{1+\rho}(1-q) u_{2, h}^{\prime} M_{I}^{\prime}=0
\end{aligned}
$$

where $M_{I}^{\prime}$ is the marginal product of capital; $u_{2, l}^{\prime}$ and $u_{2, h}^{\prime}$ are the second period marginal utilities, for the cases where the policy maker is ousted and stays in power, respectively. We can apply (24) to infer

\section{Claim 2}

$\frac{d S}{d q}>0 ; \quad \frac{d I}{d q}<0 ; \quad \frac{d I *}{d q}>0$-- Higher probability of regime change induces the present policy maker to increase savings, channeling them to offshore accounts via capital flight, and to reduce the investment, $I$. The outside party would have the opposite incentive: higher probability of regime change will increase the investment financed, $I^{*}$. Assuming that part of this investment is financed by foreign capital, we would observe that higher probability of regime change would increase both capital flight and capital inflow, implying that the de-facto financial openness increases with the probability of regime change. 
Greater commercial openness associated with greater availability of natural resources would lead to greater financial openness, as has been the case in the public finance model. This example also illustrates that with opportunistic behavior, the combination of policy uncertainty and polarization would lead to greater de-facto financial openness. ${ }^{8}$ Note the similarity of the predictions of the opportunistic and the public finance approaches - in both cases, less cohesive social organization, greater political uncertainty and greater commercial openness are associated with higher de-facto financial openness.

\section{The Empirical model}

This section reviews the methodology, the data, and the main results. For greater detail, Appendix B summarizes the definition and the sources of the variables used in this study.

\subsection{Methodology}

In the previous section, we suggested a number of characteristics that possibly determine the degree of financial openness (or alternatively, financial repression). In order to provide further motivation for this line of research we now empirically examine some of the hypotheses outlined above.

We estimate the possible statistical significance of various sources of financial repression by positing a linear structure for the determination of the level of financial openness whereby:

$$
F O_{i t}=\alpha+\beta_{1} X_{i t}+\beta_{2} \overline{C O}_{i t-1}+\beta_{3} P_{i t}+\varepsilon_{i t}, \text { with } \varepsilon_{i t}=\rho \varepsilon_{i t-1}+\mu_{i t} .
$$

The dependent variable $\left(F O_{i t}\right)$, financial openness for country $i$ at time $t$, is assumed to be dependent on an intercept (or alternatively separate country or regional intercepts), a vector $X_{i t}$ of macroeconomic control variables, average of lagged commercial openness

\footnotetext{
${ }^{8}$ In this example, polarization refers to the observation that the surplus is divided unequally among competing parties - the policy maker controls the surplus and uses it to maximize his expected utility, which differs from the expected utility of the outside party. In this example, the political uncertainty is summarized by the probability of ousting the present regime, thereby shifting the future control of the surplus to the outside party. Our example illustrates that, starting from the case of no political uncertainty $[q=0$ ], higher probability of turnover will increase both capital flight and capital inflow, increasing defacto financial openness at a rate that depends positively on the commercial openness of the economy.
} 
$\left(\overline{C O}_{i t-1}\right)$, a vector of political-institutional variables $\left(P_{i t}\right)$ and an error term. The variables examined are described below. The error term is assumed to have an $\operatorname{AR}(1)$ structure with $\mu$ iid. ${ }^{9}$

A Durbin-Watson statistic for all iterations of the model strongly indicates that the error terms are autocorrelated. The autocorrelation coefficient was always estimated to be about 0.7-0.9. We chose to estimate the model using the Prais-Winsten algorithm. The Prais-Winsten procedure is a two-step FGLS procedure that utilizes the estimated correlation coefficient obtained from the Durbin-Watson statistic from the first-stage OLS regression as the initial autocorrelation value and reiterates the second step FGLS using the whole sample till convergence (typically 2-3 iterations). ${ }^{10}$

\section{$3.2 \quad$ The data}

Appendix B provides a detailed summary of the variables and sources. We measure de facto financial openness using the sum of total capital inflows and outflows (in absolute values) measured as a percent of gross domestic product. Capital flows are the sum of FDI, portfolio flows and other investments. This measure is exactly analogous to the standard measure of commercial openness, which we employ as an independent variable in our regressions. The financial openness variable was previously used by Wei and $\mathrm{Wu}(2002){ }^{11}$

Tables 1A-1B describe our data for financial openness. Specifically, table 1A presents averages for financial openness for geographical regions, decades and the estimation samples we use. We find that for developing countries in general and in particular for Asian, African and Middle Eastern countries, financial openness decreased during the 1980s but rebounded and surpassed previous levels in the 1990s. This trend is most pronounced for the East Asian countries for which capital flows was 11.2\% of GDP during the $1970 \mathrm{~s}, 8.5 \%$ during the $1980 \mathrm{~s}$ and $16.5 \%$ during the $1990 \mathrm{~s} .{ }^{12}$ Developed

\footnotetext{
${ }^{9} E\left(\mu_{t}\right)=0 ; E\left(\mu_{t}^{2}\right)=\sigma_{u}^{2}$; and $\operatorname{Cov}\left(\mu_{t}, \mu_{s}\right)=0$ for $t \neq s$.

${ }^{10}$ For technical details see Greene (2000, pp. 546-550) and Greene (2002, E7 pp. 4-7). We use Limdep in all our estimations.

${ }^{11}$ We thank Shang-Jin Wei for making this data available to us. The data originates from the IMF's Balance of Payments Statistics database. See also Lane and Milesi-Ferretti (2001) for insightful analysis of the net asset position of nations, based upon careful aggregations of the IMF's database.

${ }^{12}$ Our data does not completely reflect the slowdown in capital flows as a result of the Asian crisis as it only covers up to 1998 .
} 
countries (OECD) do not show this trend but show a continual increase in financial openness (from $7.3 \%$ to $9.3 \%$ to $16.8 \%$ for the 1970 s, 1980 s and 1990 s respectively). Interestingly, Latin America shows a similar continuous trend in spite of the 1980s debt crisis.

For our commercial openness index, we average the sum of exports and imports as a percentage of GDP over the previous 4 years ( $t-1$ to $t-4)$. By averaging, we smooth out any fluctuations due to temporary changes in the terms of trade and obtain a more robust finding in our multivariate analysis with respect to the temporal effect of commercial openness on financial openness. We also investigate the dynamic structure of the interaction between commercial and financial openness using annual data for both.

Table 1B presents the correlation coefficients between our financial openness measure and the commercial openness measure (trade over GDP). Bivariate analysis clearly shows a partial correlation between the two types of openness (both when commercial openness is measured annually and when it is averaged for the previous 4 years). Notably, the correlation appears to be significantly weaker for Latin American countries. We undertake a multivariate analysis of this issue in the following sections. The financial openness index measures gross capital flows. Accordingly, we also show, in column 3 of table 1B, the correlation of our gross flows measure with net flows (the current account). We find that there is only a weak and unstable correlation between the two (in some of our sub-samples the correlation is even negative).

Figures 1 and 2 further describe the correlations between the financial openness measure, commercial (trade) openness, and the current account (net financial flows) across time. As previously observed, there is an apparent partial correlation between the openness measures, but a much weaker relationship between gross and net financial flows. Furthermore, the partial correlation between commercial and financial openness appears to be more pronounced for the 1990s than it was for the 1980s. ${ }^{13}$

As the previous theoretical discussion suggests, one of the determinants of $d e$ facto financial openness should be legal impediments to financial flows (de jure financial openness). Accordingly, we include in our multivariate analysis a binary measure for

\footnotetext{
${ }^{13}$ The data cover the years 1980-1989 and 1990-1998. We do not present data for the 1970s as we do not have a sufficient number of observations on trade openness for that decade to allow for any robust conclusions.
} 
restrictions on the capital account and/or the current account. Both indicators are taken from the IMF's Annual Report on Exchange Arrangements and Exchange Restrictions. These binary measures, which we combine to make a single $0 / 1$ indicator of legal restrictions, are the only internationally comparable measures of de jure financial openness available for our sample of countries and time period. ${ }^{14}$

For the political-economy determinants of financial openness, we concentrate our empirical investigation on three political-institutional measures. In the first, we employ a variable that measures the degree of democratic rule. Our democracy index is taken from the Polity IV project and ranges from -10 (fully autocratic) to +10 (fully democratic). ${ }^{15}$

This approach follows from Cukierman, Edwards and Tabellini (1992); namely, that functioning democracies will tend to have more efficient tax collection systems. In our theoretical work, we argue that the degree of tax collection costs will determine the degree of financial repression and to further examine this hypothesis we investigate whether the capacity of the political system to prevent friction (and consequently mediate conflicts through the political arena and thus facilitate more efficient tax and other regulatory structures), is a relevant measure. Again, we expect less polarized societies and those in which conflicts are solved peacefully within the political system to have more efficient tax collection mechanisms in place.

We employ a variable that measures the degree of political competition within a polity. This index combines two dimensions of political competition: (1) the degree of institutionalization, or organization, of political competition and (2) the extent of government restrictions on political competition. Combined, this measure identifies ten broad patterns of political competition that roughly correspond with the degree of “democraticness" of political competition within a polity (Marshall and Jaggers, 2000). As Marshall and Jaggers (2000, p. 79) note "[t]he polar opposite [to a competitive political system] is unregulated participation, in which there are no enduring national political organizations and no effective regime controls on political activity. In such

\footnotetext{
${ }^{14}$ We thank Michael Hutchison and Reuven Glick for making these data available to us. A thorough description of these data is found in Glick and Hutchison (forthcoming).

${ }^{15}$ The "Polity IV database includes annual measures for both institutionalized democracy (DEMOC) and autocracy (AUTOC), as many polities exhibit qualities of both these distinct authority patterns....A third indicator, POLITY, is derived simply by subtracting the AUTOC value from the DEMOC value; this
} 
situations political competition is fluid and often characterized by recurring, contentious interactions and shifting coalitions of strongly partisan groups" (italics ours). The 1-10 index defines steps between 1 (repressed competition -such as in totalitarian systems or military dictatorships) and 10 (institutionalized open electoral participation). As we show in the next section, this variable is highly correlated with the democracy-autocracy measure described above.

Another political-economy variable we use to examine the robustness of our results comes from a political data set constructed at the World Bank (Beck et al. 2001 and Keefer, 2002). As we hypothesized that more polarized social and institutional arrangements will affect the efficiency of tax collections, we use an index that measures the fractionalization within government. This variable is constructed from a Herfindahl Index for government, which is obtained by summing the squared seat shares of all parties in the government. Thus, a completely unified government will have an index of 1 and a government that is composed of many small parties will have a smaller index. ${ }^{16}$

Following the work of Wei (2000) and Dreher and Siemers (2003), we examine whether corruption matters for the degree of financial openness. To that end, we use a measure of corruption that is taken from the International Country Risk Guide. The data are available in monthly observations. We obtain annual observations from 1982 onward by averaging the monthly data points for each year. This index ranges from -6 (low probability/risk of encountering corruption) to 0 (high risk of corruption).

Table 2 presents the correlation coefficients for political variables. As noted earlier, the variable measuring political competition uses definitions related to the index measuring the regime's autocratic/democratic nature. Consequently, these variables are highly correlated (correlation of 0.94 ). Besides this pair, the other political variables do not seem significantly correlated and thus we include a number of them in our regressions.

In order to insure our results are not driven by a 'missing variables' bias, we include a host of macroeconomic control variables. In all regressions we use the inflation 
rate (changes in the $\mathrm{CPI}$ ), per capita gross domestic product (measured in PPP dollars), the government's budget surplus (as a percent of GDP), and a world interest rate (proxied by the US Treasury Bill 1-year rate). All the macroeconomic data are taken from the World Bank's World Development Indicators (2001 edition). In order to examine whether the occurrence of financial crises contaminates our result, as they might systematically change the relationship between financial openness and our control variables, we also include a crisis measure in a number of regressions. ${ }^{17}$

A priori, we see no reason to restrict our benchmark sample and therefore attempted to include all 205 countries and territories for which data are available in the 2001 edition of the World Bank's World Development Indicators (WDI). Our control variables, though, are available for only a subset of this group. Most importantly, most of the data on financial flows as well as the data on corruption are typically available only from the 1980s and only for a much smaller set of countries. Nevertheless, in most cases, our data set is an annual panel of 83 countries for the years 1982-1998.

We further investigate the robustness of our results by examining various subsamples. Notably, we hypothesize that results for developed (OECD) countries might be different from those for developing countries. We thus repeat our regressions for developed economies - which we define as those economies that were members of the OECD in 1990. As our focus is developing countries we include most of the regression results for this sub-sample. These are defined as all the countries included in the 2001 edition of the $W D I$ excluding OECD countries and island economies (as these are often used as off-shore banking centers and their level of de facto financial openness is often dramatically different from other countries). For a summary of the information described in this section, see appendix B.

\subsection{Estimation Results}

Table 3 includes results for our benchmark regressions. As documented in the previous section, all the estimations were obtained by assuming an $\mathrm{AR}(1)$ process and

\footnotetext{
${ }^{16}$ This index equals NA if there is no parliament. If there are any government parties where seats are unknown (cell is blank), the index is also blank. Independents are calculated as if they were individual parties with one seat each.

${ }^{17}$ For details see footnote \#20.
} 
using the Prais-Winsten algorithm. We consistently find a very high autocorrelation coefficient (between 0.73 and 0.88 ) with what appear to be very accurately estimated values (very high t-statistics). For the first stage regression, the $\mathrm{R}^{2}$ is between 0.20 and 0.67 depending on the exact specification and sample used. ${ }^{18}$ For the second stage, the model converges very quickly (within two iterations) and most of the coefficients for the benchmark control variables appear robust to the inclusion and exclusion of other variables. In column (1) of table 3, which includes the full sample (829 observations), we already observe many of the results that remain throughout the various iterations of this simple model.

In examining the independent variables, we first turn to our control macrovariables. The coefficient for per-capita GDP is always significantly positive - i.e., an increase in GDP per capita increases financial openness (except for a regression containing only OECD countries in which the coefficient is insignificant). We find that an increase of PPP\$* 1000 will facilitate a 0.14 to 2.28 percentage points increase in the volume of capital flows (as percent of GDP). The ratio of budget surplus to GDP is occasionally significant and always negative for developing countries. A bigger budget deficit will increase de facto financial openness. Again, this result does not hold for our OECD sub-sample; for this case, reported in table 3 column (2), the budget surplus coefficient is positive and significant. ${ }^{19}$ The inflation rate and the world interest rate (proxied by the US T-Bill rate) are always insignificantly different from zero. But, as with the previous results, the coefficients for inflation and the world interest rate seem to be different for the OECD sub-sample; although these are still insignificant for standard significance levels, the effect of inflation on financial openness is larger (and negative) for the OECD countries and the effect of the US T-Bill rate is smaller. Both these results correspond with our intuition. We also include a binary variable for the 1990s and as we expected the coefficient for this variable is always positive and significant; i.e., the 1990s

\footnotetext{
${ }^{18}$ The higher $\mathrm{R}^{2}$ values are generally for the models that include more political/institutional variables and for the developing and OECD sub-samples.

${ }^{19}$ The disparity between the impacts of budget surplus in developing and OECD countries may be explained by the differential cyclical patterns of fiscal policy. In contrast to the OECD countries, fiscal policy tends to be pro-cyclical in developing countries: i.e., government spending drops and taxes increase during recessions. Financial crises tend to lead to recessions in developing countries, inducing abrupt fiscal adjustment, reducing fiscal deficits. These observations may lead to the positive association between
} 
saw an across-the-board increase in financial openness (increased capital flows). This increase in capital flows is found to be between 1.3 and 4.9 percent of GDP.

Our first interesting empirical finding is that the trade openness coefficient (ratio of exports and imports to GDP) is always positive and highly significant. As this variable describes the average openness over the previous four years we find that a history of more commercial openness will tend to increase financial openness significantly. This result is robust to all the iterations we present in tables 3 and .

Before discussing our empirical analysis of the political-economy determinants of international financial flows, we note that including the corruption variable in our regressions also yields negative and significant coefficients in almost all the iterations of the model we examined. ${ }^{20}$ Similar results are analyzed in detail in Wei (2000) and Dreher and Siemers (2003).

Our foci in this section are the political-economy variables. First, we examine the affect of the nature of the political regime on financial openness (this index is between 10 - full democracy and -10 - full autocracy). For the full sample (table 3 column 1) and the developing countries sub-samples (table 3 column 3 ) the coefficient for this variable is negative, significant and apparently large. ${ }^{21}$ Any one-point increase in this index (out of the 20 points difference between full autocracy and democracy) reduces financial openness (international financial flows) by almost one-half a percentage point of GDP. The effect is about half as large when we do not control for the level of corruption (reported in table 3 column 4).

Since the results for the OECD sub-sample are consistently different, and our theoretical modeling is focused on developing countries, we give most attention to the developing countries sub-sample (these include all non-OECD countries that are not islands/financial-centers). Columns 5 and 6 in table 3 repeat our specification for the developing countries sample but exclude the regime variable in column 5 and both the

smaller budget deficits and lower de facto financial openness [see Gavin, Hausmann, Perotti and Talvi (1996), Aizenman, Gavin and Hausmann (2000) and Talvi and Vegh (2000)].

${ }^{20}$ Once more, this result does not hold for the OECD sub-sample (reported in table 3 column 2). In this case, the coefficient is still positive but insignificant. Variability of the corruption variable for the OECD sub-sample is much lower.

${ }^{21}$ For the OECD sample (table 3 column 2), the coefficient has the same sign and magnitude but is statistically insignificant. 
regime and corruption measures in column 6 . In both cases, we find that all the other results reported above remain robust to these omissions.

Table 4 presents information on the quantitative significance of our findings for the benchmark model. For the sample of developing countries, we find that a one standard deviation increase in the commercial openness is associated with a 9.5 percentage points increase in de-facto financial openness (percent of GDP), a one standard deviation in the increase in the democratization index reduces financial openness by 3.5 percentage points, and a one standard deviation increase in corruption is associated with a reduction of financial openness by 3.1 percentage points. Similarly, the corresponding associations for the whole sample are 12.3, 3.1 and 2.9. Furthermore, a developing country will have higher financial openness (measured as 3 additional percentage points of GDP), were it to have the median level of trade openness of an OECD country; and would be $2.2 \%$ less openness were it as democratic as the typical OECD country and $4 \%$ more open to financial flows were is less corrupt as the typical developed country.

In table 5 columns (1)-(4) we further investigate the political-economy nature of financial openness by replacing the democracy/autocracy (regime) variable with two others: a measure of political competition, and an index of government fractionalization. For the political competition variable, we find that increased institutionalized competition within the polity decreases financial openness. This result is not empirically puzzling considering that this variable is highly correlated with our measure of democracy/autocracy (even though the variable was created using different criteria). Thus, a more openly competitive, free and inclusive political system will lead to lower levels of financial openness after controlling for incomes, macroeconomic policy (inflation and budget surpluses), interest rates and commercial openness. As we observed before, this effect is more perceptible and significant once corruption is controlled for as well.

For the government fractionalization index (reported in table 5 columns 3 and 4), we find that the more a government is fractionalized (the ruling coalition includes more political parties), the higher is financial openness. Quantitatively, the estimated 
coefficient of 1.4-1.9 does not seem to suggest a very large effect on the level of international financial flows.

In column (5) of table 5 we re-estimate our benchmark specification (table 3 column 3) but also include the de-jure measure of financial openness. Interestingly, the coefficient for this binary measure of restrictions on the capital and current accounts is not significant in this specification nor in other specifications we ran. Our main results with respect to commercial openness and the political regime remain significant even when the de jure measure is included; though the corruption coefficient is no longer significant.

\subsection{Robustness of Estimation Results}

In addition to the specifications discussed above, we tested a number of alternative specifications of our empirical model in order to verify the robustness of our results. Because of space considerations we do not include the full specifications in our tables but all these results are available upon request.

First, we hypothesized that financial crises (either banking or currency crises) might significantly affect the level of financial openness in general and more specifically the use of financial repression for generating government revenues. Interestingly, in all iterations of the model we attempted, none of the coefficients for these variables comes out significant for the developing countries sample (nor for the other samples). ${ }^{22}$

Second, besides including the average of past commercial openness, we also included in our specification the contemporaneous TRADE/GDP variable and obtained the following: In all cases, the lagged commercial openness variable remains positive and highly significant. For the developing countries sample as well as the whole sample, the lagged average is positive and highly significant with a now larger coefficient $(0.20$ and 0.21 respectively) while the contemporaneous variable is negative and significant. For the OECD sample, the lagged average is still positive and highly significant while the

\footnotetext{
${ }^{22}$ We utilized a number of variants of these binary indicators (currency crisis and banking crisis, their onset year only, and these separately or together in the same specification) and we cannot reject the null (no effect). For currency crises, our indicator is identified by periods in which an index, composed of a weighted average of the real exchange rate and foreign reserves, changed dramatically - by more than 2 standard deviations. This measure is described in detail and evaluated in Hutchison and Noy (2002). The
} 
contemporaneous variable is now positive but insignificant. The sum of the two coefficients (summarizing the effect of commercial openness both past and present) is $0.05,0.06$, and 0.09 , for the developing, OECD and the whole sample, respectively. This sum is always positive and highly significant for the three different samples. ${ }^{23}$

As the political and institutional variables we use do not vary sufficiently over time we do not present results for the model estimated with country effects. Typically, the goodness of fit is higher but the independent political-institutional variables lose some of their statistical significance (as would be expected). We include regional effects (binary variables for Latin America and East Asia) in our large and developing countries samples. We also experiment with time effects, but find that no additional significance is gained by those besides a significant finding for the 1990s (reported above).

banking crisis binary indicator is taken from Caprio and Klingebiel (1999) and is analyzed in Arteta and Eichengreen (2002) and Hutchison and Noy (forthcoming).

${ }^{23}$ One possible interpretation is that major recessions in developing countries [potentially triggered by capital flight] are associated with a drop in commercial openness, as would be the case if the drop in imports dominated any increase in exports. Likewise, capital flight may increase financial openness. It is difficult to provide a better rationale for it without desegregating financial openness into its various sub accounts. 


\section{4. $\quad$ Concluding remarks}

Our analysis indicates that de-facto financial openness of developing countries is a complex endogenous variable, systematically impacted by economic and political economy factors which include commercial openness, democratization and corruption. For the sample of developing countries, we find that a one standard deviation increase in the commercial openness index is associated with a 9.5 percent increase in de-facto financial openness (international financial flows as percent of GDP), a one standard deviation increase in the democratization index reduces financial openness by 3.5 percent, and a one standard deviation increase in corruption is associated with a 3 percent reduction of financial openness [see Table 4].

The de-facto financial openness is the outcome of both efficiency and political economy considerations; hence one should be careful in attaching normative implications to these findings without having a good model of the economy. Yet, the results reported in this paper may provide some guidelines to policy makers. A country that undergoes rapid commercial integration will find it impractical to enforce rigid financial repression. Hence, the question for China is not if, but when and how to implement de-jure financial integration. To economists that are concerned about the possibility that financial integration may lead to greater instability, our paper suggests that the process of democratization may provide the side benefit of reducing financial openness. And to economists who worry that some developing countries may find it difficult to rely on external financing, steps to reduce corruption should make it easier to overcome this obstacle.

While de-facto financial openness is a useful concept, it combines capital flows motivated by political economy considerations with those motivated by efficiency considerations. A remaining challenge is to find a way to disaggregate de-facto financial openness into its various components. Additionally, a more direct empirical investigation into some of our hypotheses is called for. For example, obtaining direct measures of tax collection efficiency (for different tax instruments) and a more direct measure of political uncertainty (in our model that is the likelihood of a future regime change) should both enable us to better estimate the degree of de-facto financial openness and investigate its links with political, political-economy and regulatory environments. 


\section{References}

Aizenman, J., M. Gavin and R. Hausmann, (2000) "Optimal Tax and debt Policy With Endogenously Imperfect Creditworthiness", Journal of International Trade \& Economic Development, Volume 9 Number: 4, pp. $367-395$.

Aizenman, Joshua (2003). "On the Hidden Links between Financial and Trade Opening”. NBER Working Paper \#9906, August.

P. Guidotti. (1994): "Capital controls, collection costs, and domestic public debt," Journal of International Money and Finance, February, pp. 41 - 54.

Akerlof, G. A. and P. M. Romer, "Looting: The Economic Underworld of Bankruptcy for Profit." Brookings Papers on Economic Activity, 2, pp. 1-60 and 70-74, (1993).

Alesina, A. And G. Tabellini (1989) "External Debt, Capital Flight, and Political Risk", Journal of International Economics, 27: 199-220.

Arteta, Carlos and Barry Eichengreen (2002). "Banking Crises in Emerging Markets: Presumptions and Evidence" in M. Blejer and M. Skreb (eds.), Exchange Rate and Financial Vulnerability in Emerging Markets, MIT Press.

Beck, Thorsten, Asli Demirgüç-Kunt and Ross Levine (2001). "New tools in comparative political economy: The Database of Political Institutions," World Bank Economic Review 15(1): 165-176.

Bekaert, G, C. R. Harvey and C. Lundblad, (2001). "Does financial liberalization spur growth?” NBER Working paper \#8245.

Boyce, J. K., and L. Ndikumana (2001): "Is Africa a Net Creditor? New Estimates of Capital Flight from Severely Indebted Sub-Saharan African Countries, 1970-1996." Journal of Development Studies, 38 (2): $27-$

Caprio Gerard and Daniela Klingebiel (1999). Episodes of Systemic and Borderline Financial Crises. Manuscript (October).

Cukierman, Alex, Sebastian Edwards and Guido Tabellini (1992). "Seigniorage and Political Instability." American Economic Review, 82(3), June, 537-555.

Dooley, M. (1988). "Capital Flight: A Response to Differences in Financial Risks," IMF Staff Papers, September 1988.

(1996): "A Survey of Literature on Controls Over International Capital Transactions," IMF Staff Papers, 43(4):639-687.

,M. and K. Kletzer (1994) "Capital Flight, External Debt and Domestic Policies," Federal Reserve Bank of San Francisco Review, Summer 1994, pp. 24- 38.

Dreher, Axel and Lars-H.R. Siemers (2003). "The Intriguing Nexus Between Corruption and Capital Account Restrictions", mimeo, June.

Gavin, M., R. Hausmann, R. Perotti and E. Talvi (1996) 'Managing Fiscal Policy in Latin America and the Caribbean: Procyclicality, Volatility, and Limited Creditworthiness', mimeo, Inter-American Development Bank. 
Giovannini, A. and M. de Melo (1993). “Government Revenue from Financial Repression,” American Economic Review 83, 953-63.

Glick, Reuven and Michael Hutchison (forthcoming). "Capital Controls and Exchange Rate Instability in Developing Economies." Journal of International Money and Finance.

Greene, W. (2000). Econometric Analysis. Prentice-Hall, New Jersey.

Greene, W. (2002). Linear models for panel data. In: LIMDEP Econometric Modeling Guide Volume 1. Plainview, NY: Econometric Software, Inc.

Henry, P. B., (2003). "Capital Account Liberalization, The Cost of Capital, and Economic Growth", American Economic Review, 93(2), May, pp. 91-96.

Hutchison, Michael and Ilan Noy (2002). "Output Costs of Currency and Balance of Payments Crises in Emerging Markets," Comparative Economic Studies, XLIV(2), Summer.

Hutchison, Michael and Ilan Noy (forthcoming). "How Bad Are Twins? Output Costs of Currency and Banking Crises" Journal of Money, Credit and Banking.

Keefer, Philip (2002). "DPI2000: Database of Political Institutions: Changes and Variable Definitions". Mimeo, The World Bank.

Kletzer K. and R. Kohli (2001). "Financial Repression and Exchange Rate Management in Developing Countries: Theory and Empirical Evidence for India," IMF working paper 01/103.

Lane, Philip R., and Giani Maria Milesi-Ferretti (2001). "The External Wealth of Nations: Measures of Foreign Assets and Liabilities for Industrial and Developing Nations," Journal of International Economics, Vol. 55, pp. 263-94.

Marshall, Monty G and Keith Jaggers (2000). "POLITY IV PROJECT - Political Regime Characteristics and Transitions, 1800-1999: Dataset Users' Manual”. Mimeo, University of Maryland.

Prasad, Eswar, Kenneth Rogoff, Shang-Jin Wei and M. Ayhan Kose (2003). "Effects of Financial Globalization on Developing Countries: Some Empirical Evidence.” Mimeo, IMF, March.

Rodrik, D. (1999): “Who Needs Capital-Account Convertibility?” in Peter Kenen (ed), Should the IMF Pursue Capital Account Convertibility? Essays in International Finance no. 207, Princeton: Princeton University Press (May).

Stiglitz, J., (2002). Globalization and Its Discontents (New York: W.W. Norton \& Company, June).

Talvi, Ernesto, and Carlos A. Vegh (2000). “Tax Base Variability and Procyclical Fiscal Policy.” NBER Working Paper No. W7499, January.

Tornell, A. and A. Velasc., (1992). "Tragedy of the Commons and Economic Growth: Why Does Capital Flow from Poor to Rich Countries?," Journal of Political Economy, 100 (6):1208-31

Wei, Shang-Jin (2000). "How Taxing is Corruption on International Investors?" The Review of Economics and Statistics, 82(1):1-11, February.

Wei, Shang-Jin and Yi Wu (2002). “The Life-And-Death Implications of Globalization.” Mimeo, IMF. 


\section{Appendix A - Derivations}

This appendix overviews the derivation of several key results.

Equation (15)

Differentiating the expected utility we infer that

$$
d V=u^{\prime}\left(C_{1}\right) d C_{1}+\frac{\phi u^{\prime}\left(C_{2, f}\right) d C_{2, f}+(1-\phi) u^{\prime}\left(C_{2, s}\right) d C_{2, s}}{1+\rho}+\frac{u\left(C_{2, f}\right)-u\left(C_{2, f}\right)}{1+\rho} d \phi=
$$

$$
\begin{aligned}
& u^{\prime}\left(C_{1}\right) d C_{1}+\frac{\phi u^{\prime}\left(C_{2, f}\right)+(1-\phi) u^{\prime}\left(C_{2, s}\right)}{1+\rho} d C_{2, f}+ \\
& \frac{(1-\phi) u^{\prime}\left(C_{2, s}\right)}{1+\rho}\left[d C_{2, s}-d C_{2, f}\right]+\frac{u\left(C_{2, f}\right)-u\left(C_{2, f}\right)}{1+\rho} d \phi
\end{aligned}
$$

Consumer's budget constraints [(5) and (6)] imply

$$
\begin{aligned}
& d C_{1}=-\left[1+S_{0, i} r_{0}\right] d t-d S-d F \\
& d C_{2}^{f}=[1+S r] d t+(1+r(1-t)) d S+S(1-t) d r . \\
& d C_{2}^{s}=d C_{2}^{f}+\left(1+r^{*}\right) d F
\end{aligned}
$$

Substituting (A2) and (A3) to (A1), and collecting terms, we infer that

$$
\begin{aligned}
& \frac{d V}{u^{\prime}\left(C_{1}\right)}=-\left[1+S_{0} r_{0}\right] d t-d S-d F+ \\
& \frac{\phi u^{\prime}\left(C_{2, f}\right)+(1-\phi) u^{\prime}\left(C_{2, f}\right)}{(1+\rho) u^{\prime}\left(C_{1}\right)}\{[1+S r] d t+(1+r(1-t)) d S+S(1-t) d r\} \\
& +\frac{(1-\phi) u^{\prime}\left(C_{2, s}\right)\left(1+r^{*}\right)}{(1+\rho) u^{\prime}\left(C_{1}\right)} d F+\frac{u\left(C_{2, f}\right)-u\left(C_{2, f}\right)}{(1+\rho) u^{\prime}\left(C_{1}\right)} d \phi
\end{aligned}
$$

Applying the first order conditions [(8), (9)] to (A4), and collecting terms, we find

$$
\frac{d V}{u^{\prime}\left(C_{1}\right)}=-\left[\bar{X}+S_{0, i} r_{0}+\frac{\bar{X}+S r}{1+r(1-t)}\right] d t+\frac{S(1-t)}{1+r(1-t)} d r+\frac{u\left(C_{2, f}\right)-u\left(C_{2, f}\right)}{(1+\rho) u^{\prime}\left(C_{1}\right)} d \phi
$$

Note that (10) implies that

$$
d r=\frac{r}{1-t} d t-\frac{[1+r(1-t)]\left[1+r^{*}-[1+r(1-t)](\Omega-1)\right]}{\left(1+r^{*}\right)(1-\phi)(1-t)} d \phi
$$


Applying (A6) to (A5) we find that

(A7)

$\frac{d V}{u^{\prime}\left(C_{1}\right)}=-\left[1+S_{0} r_{0}+\frac{1}{1+r(1-t)}\right] d t+\frac{1+r^{*}-[1+r(1-t)](\Omega-1)}{\left(1+r^{*}\right)(1-\phi)} S d \phi+\frac{u\left(C_{2, f}\right)-u\left(C_{2, f}\right)}{(1+\rho) u^{\prime}\left(C_{1}\right)} d \phi$

Equation (15) is obtained from (A7), using the fact that $d \phi=\phi_{\tau}^{\prime} d \tau$.

\section{Claim 1}

Recall that the first order condition determining optimal financial repression is

(A8) $\frac{d V}{d \tau} \frac{1}{u^{\prime}\left(C_{1}\right)}=0$

where $\frac{d V}{d \tau} \frac{1}{u^{\prime}\left(C_{1}\right)}$ is given by (15). Denoting the RHS of (15) by $\mathfrak{R}$, and the optimal financial repression by $\widetilde{\tau}$, the implicit function theorem and the second order condition for maximization imply that

$$
\text { (A9) } \quad \operatorname{sign} \frac{d \tilde{\tau}}{d \lambda}=\operatorname{sign} \frac{\partial \Re}{\partial \lambda} \text {. }
$$

Assuming that the initial equilibrium is in the vicinity of low financial repression, we can apply (16) and (17):

$$
\begin{aligned}
& \operatorname{sign} \frac{\partial \tilde{\tau}}{\partial \lambda}=\operatorname{sign} \frac{\partial \Re}{\partial \lambda}=\operatorname{sign} \frac{\partial\left[-\left.\frac{d t}{d \tau}\right|_{\tau=0}\right]}{\partial \lambda}= \\
& \operatorname{sign} \frac{S\left[1+\lambda \frac{t}{1-t}\right] \phi_{\tau}^{\prime}-1+\lambda \frac{t r^{*}}{1+r^{*}}}{\left\{1+\frac{1}{1+r^{*}}+S_{0} r_{0}\right\}(1-\lambda)+\lambda \frac{r^{*}}{1+r^{*}}\left[(1-\lambda) t\left\{1+S_{0}\left(1+r_{0}\right)\right\}-\frac{S}{1-t}\right]}>0
\end{aligned} .
$$

Similar logic implies that

(A11) $\operatorname{sign} \frac{d \tilde{\tau}}{d \beta}=\operatorname{sign} \frac{\partial \Re}{\partial \beta}<0 ; \operatorname{sign} \frac{d \tilde{\tau}}{d G}=\operatorname{sign} \frac{\partial \Re}{\partial t}>0$. 
Appendix B - Data Sources and Samples

\begin{tabular}{|c|c|c|}
\hline Code & Source & Description \\
\hline KTOTAL & IMF-BOP statistics a : Wei (2002) & $\begin{array}{l}\text { Sum of capital inflows and outflows } \\
\text { (\% of GDP) }\end{array}$ \\
\hline GDPPCPP & $W D I^{\text {b }: ~ N Y . G D P . P C A P . P P . C D ~}$ & $\begin{array}{l}\text { GDP per capita, PPP (current } \\
\text { international } \$ \text { ) }\end{array}$ \\
\hline TRADG & WDI: TG.VAL.TOTL.GG.ZS & $\begin{array}{l}\text { Sum of exports and imports (\% of } \\
\text { goods GDP) }\end{array}$ \\
\hline TRADGAV & WDI: TG.VAL.TOTL.GG.ZS & Average for TRADG for $t-1, \ldots, t-4$ \\
\hline DLCPI & WDI: FP.CPI.TOTL.ZG & Inflation, consumer prices (annual \%) \\
\hline BDGTG & WDI: GB.BAL.OVRL.GD.ZS & $\begin{array}{l}\text { Overall budget deficit, including } \\
\text { grants ( } \% \text { of GDP) }\end{array}$ \\
\hline USTBILL & $I M F-I F S^{c}$ & Interest rate on U.S. Treasury bill \\
\hline CORRUPT & PRS: International Country Risk Guide & Level of Corruption $^{d}$ \\
\hline POLITY2 & POLITY IV project & Political regime type ${ }^{\mathrm{e}}$ \\
\hline POLCOMP & POLITY IV project & Degree of political competition ${ }^{f}$ \\
\hline HERFGOV & World Bank's political dataset & Herfindehl index for ruling coalition ${ }^{g}$ \\
\hline KKCCAR & IMF- $E A E R^{h}$ & $\begin{array}{l}\text { Binary measure for current account } \\
\text { and/or capital account restrictions }\end{array}$ \\
\hline
\end{tabular}

Samples (1982-1998) '

\begin{tabular}{ll}
\hline ALL & All countries in the 2001 edition of the WDI (83 countries) \\
OECD & OECD countries ( 21 countries) \\
& Developing countries - defined as all countries excluding OECD countries and \\
isEV & island states ( 60 countries $)$
\end{tabular}

${ }^{a}$ The IMF's Balance-of-Payments Statistics.

${ }^{\mathrm{b}}$ The World Bank's World Development Indicators.

' The IMF's International Finance Statistics.

${ }^{\mathrm{d}}$ This index runs from -6 (low probability/risk of encountering corruption) to 0 (highly corrupt).

e The index runs between -10 (fully autocratic) to +10 (fully democratic).

${ }^{f}$ The index defines incremental steps between 1 (repressed competition-such as in totalitarian systems or military dictatorships) and 10 (institutionalized open electoral participation).

${ }^{g}$ The index is constructed by summing the squared seat shares of all parties in the government. Thus, the index runs between 0 and 1 (a single party in the coalition).

${ }^{h}$ The IMF's Annual Report on Exchange Arrangements and Exchange Restrictions; see Glick and Hutchison (forthcoming).

' Data availability further constrained our samples. Thus, the numbers below reflect countries for which data were available for the specifications described in table 3 columns 1-3 (but not necessarily for the whole 1982-1998 time period for each country). 
Table 1A. Financial Openness - Descriptive Statistics

\begin{tabular}{lcccc}
\hline & $1970 \mathrm{~s}$ & $1980 \mathrm{~s}$ & $1990 \mathrm{~s}$ & All years \\
\hline \hline Developing countries & 6.23 & 5.43 & 8.63 & 6.82 \\
OECD countries & 7.34 & 9.31 & 16.79 & 11.50 \\
East Asia & 11.20 & 8.47 & 16.53 & 12.38 \\
Latin America & 4.81 & 6.05 & 8.15 & 6.53 \\
Other $^{\text {a }}$ & 6.21 & 4.89 & 7.10 & 5.93 \\
All & 6.83 & 6.96 & 10.35 & 8.23 \\
\hline
\end{tabular}

${ }^{a}$ Other includes Africa (North and Sub-Saharan), Middle East and South Asia.

Table 1B. Financial Openness - Correlations

\begin{tabular}{lccc}
\hline $\begin{array}{l}\text { Correlation of financial } \\
\text { openness measure with... }\end{array}$ & $\begin{array}{c}\text { Comm. openness } \\
(\mathrm{t})\end{array}$ & $\begin{array}{c}\text { Comm. openness } \\
\text { (previous average) }\end{array}$ & Current account \\
\hline \hline Developing countries & 0.34 & 0.34 & 0.25 \\
OECD countries & 0.39 & 0.37 & -0.04 \\
East Asia & 0.32 & 0.27 & -0.23 \\
Latin America & 0.25 & 0.18 & 0.20 \\
Other $^{\text {a }}$ & 0.34 & 0.39 & 0.36 \\
All & 0.39 & 0.38 & 0.23 \\
\hline
\end{tabular}

${ }^{\mathrm{a}}$ Other includes Africa (North and Sub-Saharan), Middle East and South Asia.

Table 2. Correlation Coefficients for Political Variables

\begin{tabular}{cccc}
\hline & POLITY2 & HERFGOV & POLCOMP \\
\hline \hline CORRUPT & -0.26 & 0.12 & -0.22 \\
POLITY2 & & -0.27 & 0.94 \\
HERFGOV & & & -0.27 \\
\hline
\end{tabular}


Table 3. Benchmark Model Results

\begin{tabular}{|c|c|c|c|c|c|c|}
\hline & (1) & (2) & (3) & (4) & (5) & (6) \\
\hline \multirow{2}{*}{ Per capita GDP } & $0.64^{* *}$ & 0.14 & $2.28^{* * *}$ & $2.14^{* * *}$ & $2.02^{* * *}$ & $1.41^{* * *}$ \\
\hline & $(2.14)$ & $(1.09)$ & $(4.09)$ & $(4.28)$ & $(3.67)$ & $(3.11)$ \\
\hline Budget surplus & $-0.26^{*}$ & $0.44^{* * *}$ & $-0.40^{* *}$ & $-0.28^{*}$ & $-0.42^{* *}$ & $-0.26^{*}$ \\
\hline (\% of GDP) & $(-1.70)$ & $(4.60)$ & $(-2.07)$ & $(-1.62)$ & $(-2.16)$ & $(-1.81)$ \\
\hline \multirow{2}{*}{ Inflation (CPI) } & 0.00 & -0.14 & 0.00 & 0.00 & 0.00 & 0.00 \\
\hline & $(-0.16)$ & $(-1.46)$ & $(-0.38)$ & $(-0.27)$ & $(-0.47)$ & $(-0.28)$ \\
\hline \multirow{2}{*}{ US Treasury bill rate } & -0.32 & -0.03 & -0.26 & -0.31 & -0.19 & -0.13 \\
\hline & $(-0.88)$ & $(-0.14)$ & $(-0.53)$ & $(-0.70)$ & $(-0.38)$ & $(-0.32)$ \\
\hline Trade openness & $0.11^{* * *}$ & $0.09^{\star \star *}$ & $0.07^{* * *}$ & $0.08^{* * *}$ & $0.08^{* * *}$ & $0.09^{* * *}$ \\
\hline (Average for $\mathrm{t}-1, \ldots, \mathrm{t}-4$ ) & $(9.08)$ & (7.99) & $(4.52)$ & $(5.51)$ & $(5.15)$ & $(7.19)$ \\
\hline \multirow{2}{*}{ Democracy/autocracy } & $-0.44^{* * *}$ & -0.40 & $-0.51^{* *}$ & $-0.26^{*}$ & & \\
\hline & $(-2.71)$ & $(-0.37)$ & $(-2.48)$ & $(-1.60)$ & & \\
\hline \multirow{2}{*}{ Corruption } & $-2.01^{* *}$ & -0.12 & $-2.74^{* *}$ & & $-1.86^{*}$ & \\
\hline & $(-2.23)$ & $(-0.25)$ & $(-2.24)$ & & $(-1.59)$ & \\
\hline \multirow{2}{*}{ The 1990s } & $4.89^{* * *}$ & $3.04^{* * *}$ & $4.65^{* *}$ & $4.04^{* *}$ & $3.52^{*}$ & $3.83^{* *}$ \\
\hline & $(2.99)$ & (3.71) & $(2.10)$ & $(2.08)$ & $(1.62)$ & $(2.17)$ \\
\hline$\rho^{a}$ & $0.88^{* * *}$ & $0.86^{* * *}$ & $0.88^{* \star *}$ & $0.88^{* * *}$ & $0.88^{* * *}$ & $0.88^{* * *}$ \\
\hline Observations & 829 & 222 & 607 & 694 & 607 & 768 \\
\hline Sample ${ }^{b}$ & ALL & OECD & DEV & DEV & DEV & DEV \\
\hline
\end{tabular}

t-statistics for all variables are given in parentheses. We denote significance levels at the $10 \%, 5 \%$ and $1 \%$ with *, ** and *** respectively.

The LHS variable is the sum of financial inflows and outflows (as \% of GDP).

Estimation using the Prais-Winsten algorithm assuming an AR(1) process for the error terms.

For definitions of variables, see appendix B.

${ }^{\mathrm{a}} \rho$ is the correlation coefficient for the $\mathrm{AR}(1)$ process: $\varepsilon_{i t}=\rho \varepsilon_{i t-1}+\mu_{i t}$.

${ }^{\mathrm{b}}$ ALL denotes the whole sample, OECD includes only OECD countries and DEV denotes the developing countries sample. For precise definitions see appendix B and text. 
Table 4. Effects of Changes in Independent Variables on Financial Openness

\begin{tabular}{|c|c|c|c|}
\hline & \multicolumn{2}{|c|}{$\begin{array}{l}\text { Effect of positive } \\
\text { change of one standard } \\
\text { deviation }\end{array}$} & $\begin{array}{l}\text { Effect of moving from the median value of } \\
\text { the variable in developing countries to the } \\
\text { median value in the OECD sample } \\
\text { Whole Sample }{ }^{a c}\end{array}$ \\
\hline Trade openness & 12.27 & 9.42 & 2.95 \\
\hline Democracy/autocracy & -3.13 & -3.51 & -2.21 \\
\hline Corruption & -2.89 & -3.12 & 4.01 \\
\hline
\end{tabular}

${ }^{\text {a }}$ Specification in table 3 column 1.

${ }^{\mathrm{b}}$ Specification in table 3 column 3.

${ }^{\mathrm{c}}$ From our data, the median developing country is less open to trade, less democratic and more corrupt. 
Table 5. Robustness - Political Variables

\begin{tabular}{|c|c|c|c|c|c|}
\hline & (1) & (2) & (3) & (4) & (5) \\
\hline Per capita GDP & $\begin{array}{r}2.26^{* * \star} \\
(3.94)\end{array}$ & $\begin{array}{r}2.15^{\star * \star} \\
(4.17)\end{array}$ & $\begin{array}{r}0.64^{* * *} \\
(5.70)\end{array}$ & $\begin{array}{l}0.33^{\star *} \\
(2.03)\end{array}$ & $\begin{array}{r}1.45^{\star \star \star} \\
(2.59)\end{array}$ \\
\hline $\begin{array}{l}\text { Budget surplus } \\
\text { (\% of GDP) }\end{array}$ & $\begin{array}{l}-0.44^{* *} \\
(-2.19)\end{array}$ & $\begin{array}{l}-0.30^{*} \\
(-1.71)\end{array}$ & $\begin{array}{r}-0.03 \\
(-0.60)\end{array}$ & $\begin{array}{c}-0.10^{*} \\
(-1.70)\end{array}$ & $\begin{array}{r}-0.28 \\
(-1.42)\end{array}$ \\
\hline Inflation (CPI) & $\begin{array}{r}0.00 \\
(-0.45)\end{array}$ & $\begin{array}{r}0.00 \\
(-0.32)\end{array}$ & $\begin{array}{r}0.00 \\
(0.02)\end{array}$ & $\begin{array}{r}0.00 \\
(-0.29)\end{array}$ & $\begin{array}{r}0.00 \\
(-0.27)\end{array}$ \\
\hline US Treasury bill rate & $\begin{array}{r}-0.26 \\
(-0.51)\end{array}$ & $\begin{array}{r}-0.27 \\
(-0.59)\end{array}$ & $\begin{array}{r}-0.30^{* * *} \\
(-2.61)\end{array}$ & $\begin{array}{r}-0.22 \\
(-1.41)\end{array}$ & $\begin{array}{r}-0.54 \\
(-1.10)\end{array}$ \\
\hline $\begin{array}{l}\text { Trade openness } \\
\text { (Average for } \mathrm{t}-1, \ldots, \mathrm{t}-4)\end{array}$ & $\begin{array}{r}0.08^{* * *} \\
(4.65)\end{array}$ & $\begin{array}{r}0.08^{* * *} \\
(5.47)\end{array}$ & $\begin{array}{l}0.05^{* * *} \\
(15.04)\end{array}$ & $\begin{array}{l}0.06^{* * *} \\
(12.88)\end{array}$ & $\begin{array}{r}0.07^{* * *} \\
(4.48)\end{array}$ \\
\hline Political competition & $\begin{array}{r}-0.67^{*} \\
(-1.75)\end{array}$ & $\begin{array}{r}-0.39 \\
(-1.19)\end{array}$ & & & \\
\hline $\begin{array}{l}\text { Government } \\
\text { fractionalization }\end{array}$ & & & $\begin{array}{r}-1.87^{* *} \\
(-2.22)\end{array}$ & $\begin{array}{r}-1.40 \\
(-1.24)\end{array}$ & \\
\hline Democracy/autocracy & & & & & $\begin{array}{r}-0.36^{*} \\
(-1.71)\end{array}$ \\
\hline $\begin{array}{l}\text { De jure financial } \\
\text { openness }\end{array}$ & & & & & $\begin{array}{r}-1.04 \\
(-0.68)\end{array}$ \\
\hline Corruption & $\begin{array}{l}-2.07^{*} \\
(-1.74)\end{array}$ & & $\begin{array}{r}0.73^{* * *} \\
(2.93)\end{array}$ & & $\begin{array}{r}1.13 \\
(0.90)\end{array}$ \\
\hline The 1990s & $\begin{array}{r}4.01^{*} \\
(1.79) \\
\end{array}$ & $\begin{array}{r}3.70^{*} \\
(1.88) \\
\end{array}$ & $\begin{array}{r}1.27^{* * *} \\
(2.56) \\
\end{array}$ & $\begin{array}{r}1.89^{* * *} \\
(2.78) \\
\end{array}$ & $\begin{array}{r}3.41^{*} \\
(1.56) \\
\end{array}$ \\
\hline$\rho^{\mathrm{a}}$ & $0.88^{\star \star *}$ & $0.88^{* * *}$ & $0.73^{* * *}$ & $0.83^{* * *}$ & $0.89^{\star * \star}$ \\
\hline Observations & 591 & 673 & 552 & 635 & 578 \\
\hline Sample ${ }^{b}$ & DEV & DEV & DEV & DEV & DEV \\
\hline
\end{tabular}

t-statistics for all variables are given in parentheses. We denote significance levels at the $10 \%, 5 \%$ and $1 \%$ with $*, * *$ and $* * *$ respectively.

The LHS variable is the sum of financial inflows and outflows (as \% of GDP).

Estimation using the Prais-Winsten algorithm assuming an AR(1) process for the error terms. For definitions of variables and samples, see appendix B.

${ }^{\mathrm{a}} \rho$ is the correlation coefficient for the $\operatorname{AR}(1)$ process: $\varepsilon_{i t}=\rho \varepsilon_{i t-1}+\mu_{i t}$.

${ }^{\mathrm{b}}$ DEV denotes the developing countries sample. 
Figure 1

Correlation of financial and trade openness

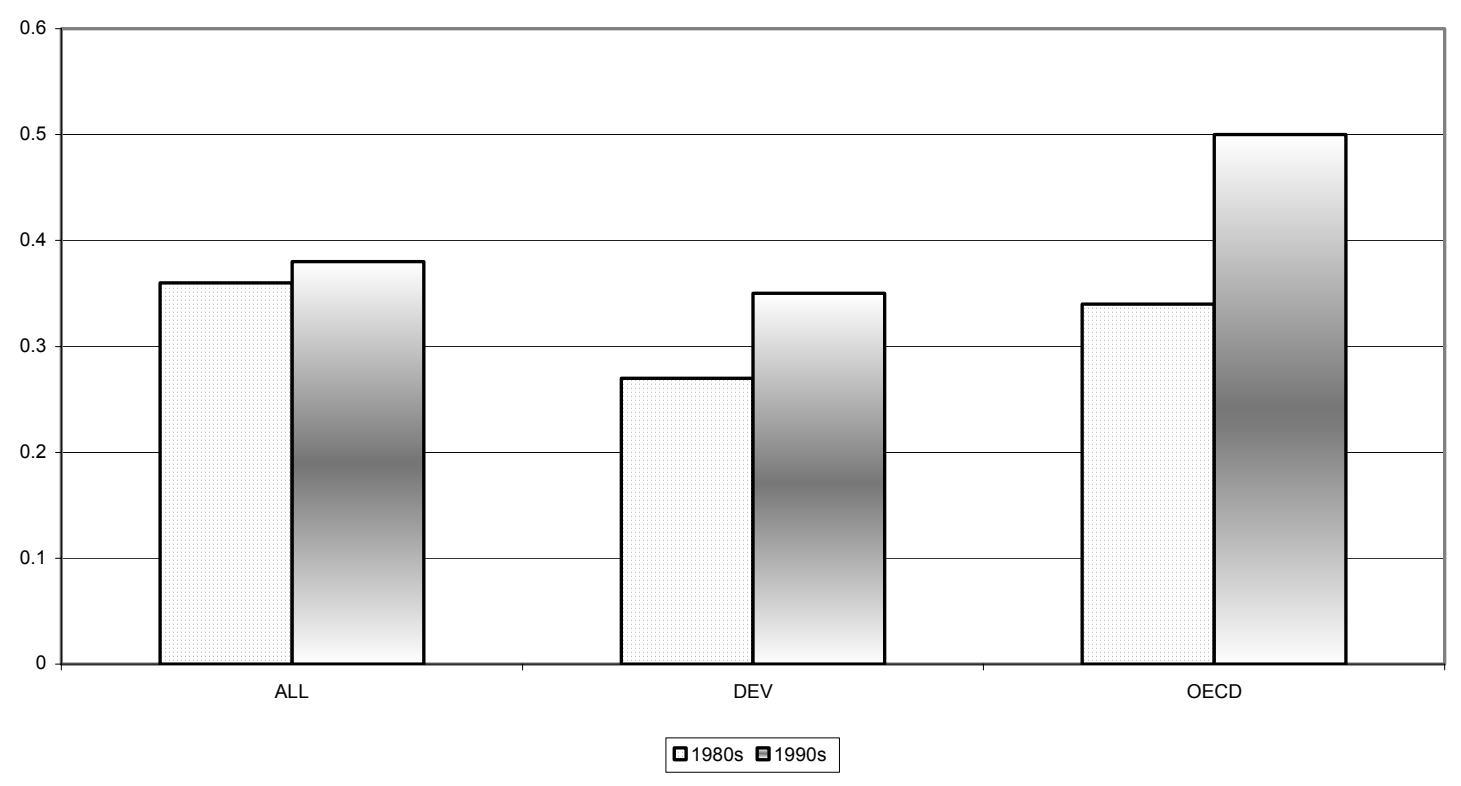

Figure 2

Correlation for financial openness (gross flows) and the current account (net flows)

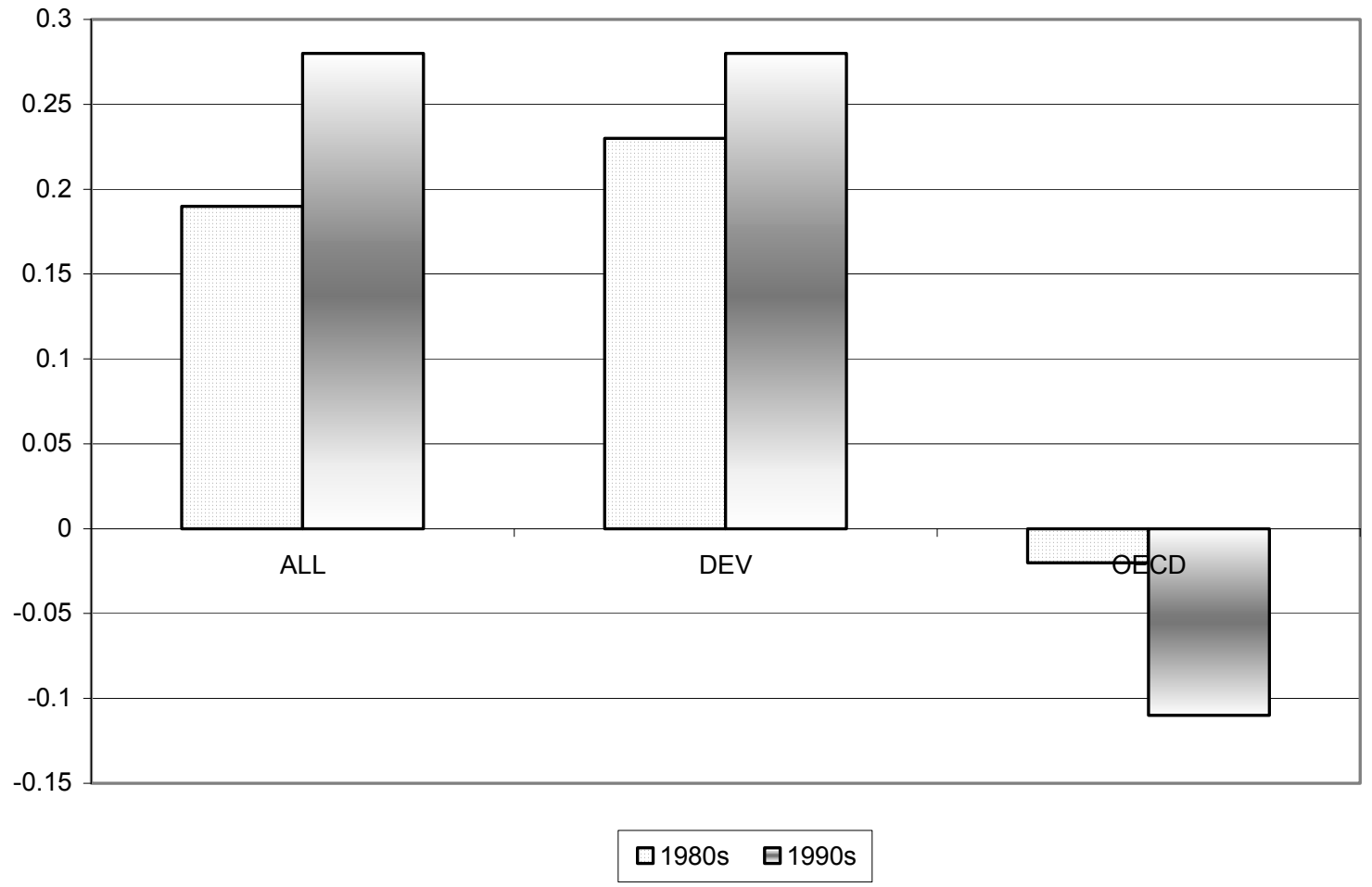

